\title{
Central venous-to-arterial carbon dioxide difference in the early postoperative care following liver transplantation
}

\author{
I Saez ${ }^{1 *}$, J Sáez², M Talayero', N González, M Catalán', JÁ Sánchez Izquierdo', JC Montejo² \\ From ESICM LIVES 2015 \\ Berlin, Germany. 3-7 October 2015
}

\begin{abstract}
Introduction
The early postoperative period after liver transplantation is characterized by a complex hemodynamic situation, due to the interaction of multiple factors, as the persistence of the hyperdynamic circulation or the increase of lactate blood levels because of the impaired hepatic clearance. The central venous-to-arterial carbon dioxide difference $\left(\mathrm{P}_{\mathrm{CVA}} \mathrm{CO}_{2}\right.$ gap) has been proposed to better identify patients with persistent global hypoperfusion.
\end{abstract}

\section{Objectives}

To analyze the ability of the $\mathrm{P}_{\mathrm{CVA}} \mathrm{CO}_{2}$ gap in the hemodynamic management after liver transplantation.

\section{Methods}

Prospective observational study including all patients admitted to the ICU after liver transplantation over a 4months study period. Demographic variables (sex, age, cause of transplantation and severity scores), hemodynamic variables, and those related to graft function and postoperative complications were recorded.Data statistical analysis was done using SPSSâ software. Quantitative variables are expressed as mean with standard deviation (SD) and qualitative variables as absolute and relative frequencies. The statistical significance of the proportion comparison was addressed by the chi-square test or Student's $\mathrm{t}$-Test with a statistical significance $\mathrm{p}<0.05$.

\section{Results}

During the study period, 24 patients were admitted to the ICU after a liver transplantation (80\% male) with a mean age of $55,9 \pm 10$ years. Mean MELD score was $15 \pm 9$;

${ }^{1}$ Hospital 12 de Octubre, Madrid, Spain

Full list of author information is available at the end of the article
Mean Child-Pugh was $8 \pm 3$. Mean ICU stay was $8 \pm 8$ days, with an overall mortality of $8 \%$. Mean hospital stay was $18 \pm 8$ days. Early graft dysfunction incidence was $12,5 \%$. Delayed extubation $(>24 \mathrm{H})$ incidence was $16 \%$ meanwhile acute renal incidence was 58\% (14\% AKIN I, $21 \%$ AKIN II y 64\% AKIN III). Two patients (8\%) presented infectious complications and four 4(16\%) developed seizures. During the 72 first hours of ICU stay, 13 patients (54\% of the sample) presented a $\mathrm{P}_{\mathrm{CVA}} \mathrm{CO}_{2}$ gap $>6 \mathrm{mmHg}$, simultaneously with a cardiac index $>3$ $1 / \mathrm{min} / \mathrm{m}^{2}$ and a mixed venous oxygen saturation $>60 \%$. Delayed extubation was associated with an elevated $\mathrm{P}_{\mathrm{CVA}} \mathrm{CO}_{2}$ gap in $30,8 \%$ of the cases vs. $0 \%$ in those with a normal $\mathrm{P}_{\mathrm{CVA}} \mathrm{CO}_{2}$ gap $(\mathrm{p}=0.98)$. An elevated $\mathrm{P}_{\mathrm{CVA}} \mathrm{CO}_{2}$ gap was associated with longer ICU stay $(11,2$ vs $4,2, \mathrm{p}=$ $0.038)$ and hospital stay $(19,6$ vs. $15,6, \mathrm{p}=0.334)$.

\section{Conclusions}

In the early postoperative care after liver transplantation, the $\mathrm{P}_{\mathrm{CVA}} \mathrm{CO}_{2}$ gap is a feasible hemodynamic parameter that could predict a worse clinical outcome.

\section{Authors' details \\ ${ }^{1}$ Hospital 12 de Octubre, Madrid, Spain. ${ }^{2}$ Hospital Infanta Leonor, Madrid, Spain.}

Published: 1 October 2015

\section{References}

1. Van Beest PA, Lont MC, Holman ND, et al: Central venous-arterial pCO2 difference as a tool in resuscitation of septic patients. Intensive Care Medicine 2013, 39:1034-1039.

2. Monnet $X$, Julien F, Ait-Hamou N, et al: Lactate and venoarterial-venous difference ratio, but not central venous saturation, predict increase in oxygen consumption in fluid responders. Crit Care Med 2013, 41:1412-1420

3. Razonable RR, Findlay JY, O'Riordan A, et al: Critical care issues in patients after liver transplantation. Liver Transplantation 2011, 17:511-527.

\section{SpringerOpen ${ }^{\circ}$}

( 2015 Saez et al.; This is an Open Access article distributed under the terms of the Creative Commons Attribution License (http:// creativecommons.org/licenses/by/4.0), which permits unrestricted use, distribution, and reproduction in any medium, provided the original work is properly cited. 
doi:10.1186/2197-425X-3-S1-A821

Cite this article as: Saez et al: Central venous-to-arterial carbon dioxide difference in the early postoperative care following liver transplantation. Intensive Care Medicine Experimental 2015 3(Suppl 1):A821.

\section{Submit your manuscript to a SpringerOpen ${ }^{\mathcal{O}}$ journal and benefit from:}

- Convenient online submission

- Rigorous peer review

- Immediate publication on acceptance

- Open access: articles freely available online

- High visibility within the field

- Retaining the copyright to your article

Submit your next manuscript at $\gg$ springeropen.com 